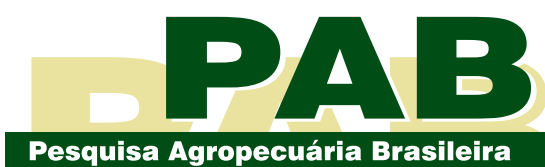

ISSN 1678-3921

Journal homepage: www.embrapa.br/pab

For manuscript submission and journal contents, access: www.scielo.br/pab
Carlos Alberto Domingues da Silva ${ }^{(1 \otimes)}(\mathrm{D}$, Josivaldo da Silva Galdino(2) (D), Thiele da Silva Carvalho ${ }^{(3)}$ (iD) and José Cola Zanuncio(4) (iD

(1) Embrapa Algodão, Rua Oswaldo Cruz, № 1.143, Centenário, CEP 58428-095 Campina Grande, PB, Brazil. E-mail: carlos.domingues-silva@embrapa.br

(2) Universidade Estadual da Paraíba, Rua Baraúnas, № 351, Universitário, CEP 58429-500 Campina Grande, PB, Brazil.

E-mail: galdinoj13@gmail.com

(3) Universidade Federal da Paraíba, Campus I, Castelo Branco, CEP 58051-900 João Pessoa, PB, Brazil. E-mail: thielecarvalho@hotmail.com

(4) Universidade Federal de Viçosa, Avenida Peter Henry Rolfs, s/no, Campus Universitário, CEP 36570-900 Viçosa, MG, Brazil.

E-mail: zanuncio@ufv.br

$\bowtie$ Corresponding author

Received

June 01, 2020

Accepted

December 08, 2020

How to cite

SILVA, C.A.D. da; GALDINO, J. da S.

CARVALHO, T. da S.; ZANUNCIO, J.C.

Biological and morphological parameters of

Dysdercus maurus fed with low- or high-oil

cotton seeds. Pesquisa Agropecuária

Brasileira, v.56, e02052, 2021. DOI: https://doi. org/10.1590/S1678-3921.pab2021.v56.02052.
Entomology/ Original Article

\section{Biological and morphological parameters of Dysdercus maurus fed with low- or high-oil cotton seeds}

\begin{abstract}
The objective of this work was to determine the biological and morphological parameters of Dysdercus maurus fed with cotton (Gossypium hirsutum) seeds with a high or low oil content, as well as to identify genotypes to be used in breeding programs as sources of resistance to this stink bug. The development, survival, and reproduction of the cotton stainer bug were determined in a completely randomized experimental design. The treatments consisted of the insect nymphs being feed with cotton seeds of the CNPA 2001-5581 (high oil content) or CNPA 2001-5087 (low content) genetic line. Survival, weight, and morphological parameters of the bug were determined. The survival of second- and third-instar nymphs and of the total nymph stage of D. maurus was lower with cotton seeds with a low oil content. The body length and head width of D. maurus adults were greater, but pronotum length and width were smaller and the females heavier with cotton seeds with a high oil content. Low-oil cotton genotypes can reduce populations of the stainer bug.
\end{abstract}

Index terms: Gossypium hirsutum, cotton stainer bug, Hemiptera, seedsucking bug.

\section{Parâmetros biológicos e morfológicos de Dysdercus maurus alimentado com sementes de algodão com baixo ou alto teor de óleo}

Resumo - O objetivo deste trabalho foi determinar os parâmetros biológicos e morfológicos de Dysdercus maurus alimentado com sementes de algodão (Gossypium hirsutum) com alto ou baixo teor de óleo, bem como identificar genótipos a serem usados em programas de melhoramento como fontes de resistência a esse percevejo. O desenvolvimento, a sobrevivência e a reprodução do percevejo manchador de algodão foram determinados em delineamento experimental inteiramente casualizado. Os tratamentos consistiram de ninfas do inseto alimentadas com sementes de algodão da linhagem genética CNPA 2001-5581 (alto teor de óleo) ou CNPA 2001-5087 (baixo teor). Foram determinados a sobrevivência, o peso e os parâmetros morfológicos do percevejo. A sobrevivência das ninfas de segundo e terceiro ínstars e do estágio total de ninfas de D. maurus foi menor com sementes de algodão com baixo teor de óleo. O comprimento do corpo e a largura da cabeça dos adultos de D. maurus foram maiores, mas o comprimento e a largura do pronoto menores e as fêmeas mais pesadas com sementes de algodão com alto teor de óleo. Genótipos de algodão com baixo teor de óleo podem reduzir as populações do percevejo.

Termos para indexação: Gossypium hirsutum, percevejo manchador do algodão, Hemiptera, percevejo sugador de sementes. 


\section{Introduction}

Cotton (Gossypium hirsutum L.) is an important crop worldwide (Sharif et al., 2019), whose fibers are used in natural textiles, seed oil for human consumption and biofuels, and cottonseed meal for animal feed (He et al., 2013; Sharif et al., 2019). In Brazil, cotton contributes significantly to agricultural economy, being grown in all regions of the country, covering an area of $1,610,300$ ha, with a production of 2,691,400 tons (IBGE, 2020). Brazil is the fourth largest cotton producer, the second largest exporter of cotton lint, and the fifth largest production park in the world, with the cotton production chain including 27,500 companies with 1.5 million direct and indirect jobs in 2020 (Araújo, 2020).

However, the crop can be attacked by several pests, among which stand out cotton stainers of the genus Dysdercus (Pyrrhocoridae), which are important seed-sucking bugs in several countries around the world (Shah, 2014; Saeed et al., 2016; Shafiq et al., 2020). Dysdercus maurus Distant, 1901 (Heteroptera: Pyrrhocoridae) is one of the most competitive species for food resources, with a wide variety of host plants and geographical distribution (Almeida \& Gonçalves, 2007). This stinkbug is one of the most destructive cotton pests in Brazil (Jorge \& Lomônaco, 2009), causing either direct damage, by destroying cotton boll tissue and mature seeds, making them unviable and wrinkled, with weight loss and reduced oil content, or indirect damage, by the inoculation of opportunistic microorganisms (bacteria and fungi), mainly staining cotton fibers (Salem et al., 2013; Sontakke et al., 2013; Azher et al., 2019).

Cotton stainers predominantly feed on cotton seeds, which contain 14 to $25 \%$ lipids (Bellaloui \& Turley, 2013; He et al., 2014, 2015; Bellaloui et al., 2015). Lipids, also called oils or fats, are the main reserve material of cotton seeds, and genetic improvement programs aim to increase their content (Carvalho et al., 2017). Lipids are generally present as glycerides (triglycerides) and unsaturated fatty acids, such as oleic (15\%), linoleic (58\%) and palmitic (26\%) acids, besides others (1\%) (Matthäus \& Özcan, 2015). These compounds are essential for seed-sucking insects (Berezina, 2017), especially in periods of prolonged energy demand, which make seeds the preferred feeding sites, from which nutrients are more easily obtained (Panizzi, 2000; Visser et al., 2017). However, seed suckers also obtain nutrients from other plant tissues, such as growing tips or flowers, in periods of seed scarcity, although, in general, these sources do not allow a complete nymph development or egg production (Panizzi, 2000).

Therefore, seed-sucking bugs can store reserves as lipids, whose content varies with the nutritional quality of genotypes (Panizzi et al., 2012). For this reason, in the present study, it was hypothesized that the biological performance of D. maurus should vary according to the oil content of cotton seeds, which requires further studies for the integrated management of this pest, in order to reduce its damage to cotton plants.

The objective of this work was to determine the biological and morphological parameters of D. maurus fed with cotton seeds with a high or low oil content, as well as to identify genotypes to be used in breeding programs as sources of resistance to this stink bug.

\section{Materials and Methods}

The study was conducted in an experimental field ( $7^{\circ} 13^{\prime} 31^{\prime \prime} \mathrm{S}$ latitude, $35^{\circ} 54^{\prime} 18^{\prime \prime} \mathrm{W}$ longitude) and in the Laboratory of Entomology of Embrapa Algodão, located in the municipality of Campina Grande, in the state of Paraíba, Brazil (7²13'32"S latitude, 3554'19"W longitude).

Dysdercus maurus specimens were collected in the field in a $50 \mathrm{~m}^{2}(10 \times 5 \mathrm{~m})$ experimental area, cultivated with the BRS Safira cotton cultivar, and were reared in the laboratory, at $25 \pm 2^{\circ} \mathrm{C}, 60 \pm 10 \%$ relative humidity, and 12-hour photophase (Mendes, 1964; Shah et al., 2016), for five generations on fresh cotton seeds without soaking in water. The used species was identified by Blöte's dichotomous key (Lima et al., 1962).

The CNPA 2001-5581 and CNPA 2001-5087 cotton genetic lines, with a high and low oil content, respectively, were cultivated in the field on March 15,2019 , in two areas of $81 \mathrm{~m}^{2}(8.1 \times 10 \mathrm{~m})$ spaced at $0.90 \times 0.20 \mathrm{~m}$, leaving one plant per pit after thinning. The plants of each area were self-fertilized, and, after their formation at 142 days, bolls were collected to determine their seed oil content and to be supplied to the cotton stainer bug. The seed oil content of 50 bolls of each genetic line of cotton was determined by solvent extraction (AOCS, 2005) (Figure 1), and the remaining cotton seeds of each genetic line in the field 
were also collected and offered to the cotton stainer bugs as food.

Per treatment, 100 fertilized $D$. maurus eggs were placed in a transparent plastic container $(6 \mathrm{~cm}$ in diameter by $2 \mathrm{~cm}$ in height) with a lid.

After hatching, 80 first-instar D. maurus nymphs were separated and kept in groups of ten per plastic container; half were fed ad libitum with cotton seeds with a high oil content and water and the other half, with cotton seeds with a low oil content and water, from the first instar until the adult stage. The experimental design was completely randomized, with two treatments and 40 replicates. The treatments consisted of the cotton stainer bug nymphs being fed with either seeds of the CNPA 2001-5581 (high oil content) or CNPA 2001-5087 (low oil content) cotton lines. The insects were kept in climate chambers, with temperature of $25 \pm 1^{\circ} \mathrm{C}$, relative humidity of $60 \pm 10 \%$, and photoperiod of 12 hours, for 96 days. Water was supplied through a cotton ball kept in the central part of the base of the container. Seeds and cotton balls were changed every two days. Dysdercus maurus adults were sexed (Mendes, 1964), separated into couples, and mated in plastic containers, where they received cotton seeds and water until their death.

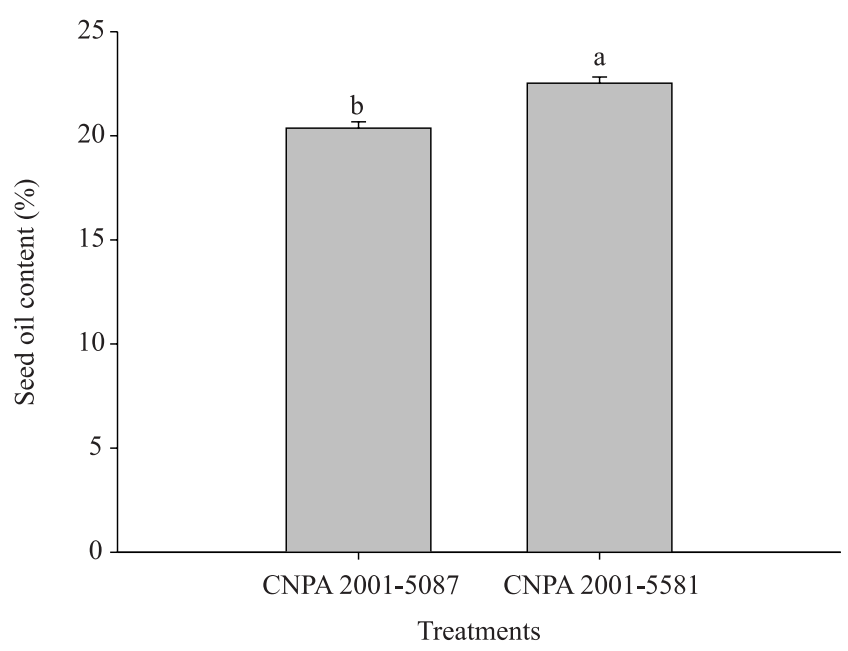

Figure 1. Oil content in cotton (Gossypium hirsutum) seeds of the CNPA 2001-5087 and CNPA 2001-5581 genetic lines, with a low and high oil content, respectively. Bars followed by the equal lowercase letters per treatment do not differ by Fisher's LSD test, at 5\% probability.
Biological observations were performed daily at 8:00 a.m. and 4:00 p.m. with the aid of a stereoscopic microscope.

The biological variables determined were: number of instars, development period and survival of each instar, development period and survival of total nymph stage, and number of nymphs that originated males or females. The periods of preoviposition, oviposition, postoviposition, longevity, fecundity, and the number and percentage of viable eggs were also evaluated.

The weight and biometrics of D. maurus were determined, respectively, using the AY220 precision analytical balance (Shimadzu Scientific Instruments, Inc., Columbia, MD, USA), with a decimal precision of $0.0001 \mathrm{~g}$, and the EL224 stereomicroscope (BEL Equipamentos Analíticos LTDA., Piracicaba, SP, Brazil), with 20-fold magnification. Five females and six males per treatment were weighed one day after emergence, had their morphological variables obtained after their death, and were preserved for up to 24 hours in $70 \%$ alcohol and then mounted with an entomological pin on Styrofoam covered by graph paper.

Oil percentage in the cotton seeds and the development data of D. maurus were subjected to the analysis of variance (Anova), and means were compared by Fisher's LSD test, at 5\% probability. Data of $D$. maurus weight and morphological parameters were subjected to the Anova, and means were compared by Tukey's test, also at 5\% probability. Statistical analyses were performed using the Saeg statistical and genetic analysis system (Ribeiro Jr., 2001).

\section{Results and Discussion}

The survival of immature stages of D. maurus varied between treatments and insect development stages (Table 1). The survival of second- and thirdinstar nymphs and of the total nymph stage of $D$. maurus was lower when the insect was fed with cotton seeds with a low oil content. However, nymph hatching and survival in the fourth and fifth instar were higher with low- and high-oil cotton seeds, respectively. This suggests that surviving nymphs depend on the oil content in the cotton seed, because the consumption of seeds with a low oil content can affect the energy demand for the metabolic processes responsible for the survival of the insect (Panizzi et al., 2012). Survival 
was lowest in the second and third instars and in the total nymph stage when cotton seeds with a low oil content were supplied. This higher mortality rate in the second and third instars partially agrees with the results obtained for the same species, but fed with Chorisia speciosa St. Hil. (Bombacaceae) seeds and with the IAC 22 cotton cultivar with a low oil seed content (Almeida \& Gonçalves, 2007), as well as for Dysdercus peruvianus Guérin-Méneville fed with seeds of this same cotton cultivar (Milano et al., 1999).

The cotton genotype also affected the development period (days) of D. maurus (Table 1). The periods of egg incubation, total nymph stage, egg to adult, and first and fourth instars were similar when the insect was fed with cotton seeds with a low or high oil content, but those of the second, third, and fifth instars differed between treatments. The duration of the second instar and of the third and fifth instars was longer for insects that were fed with cotton seeds with a low and high oil content, respectively. This shows that variations in the duration of the second, third, and fifth instars of D. maurus are related to the oil content of the cotton seeds. In general, when seed-sucking cotton stainer nymphs store more lipids, they accumulate less water in their bodies, which may increase metabolic water production to compensate for water deficiency, affecting their development period (Mishra et al., 2004; Sláma \& Lukáš, 2016). However, this depends on juvenile hormone production and total metabolic lipid combustion in the diet, as reported for Pyrrhocoris apterus L. (Jindra et al., 2013; Vinokurov et al., 2014; Sláma \& Lukáš, 2016). In the present study, the fifth instar of $D$. maurus always lasted longer than the others in both cotton genotypes. This is common in Heteroptera, since intense changes occur when the insects are nearing maturity and a larger amount of nutrients is required for molting and to produce adults with a good reproductive potential (Panizzi et al., 2012).

The periods of preoviposition, oviposition, and postoviposition, as well as longevity and fecundity, were similar for $D$. maurus females fed with cotton seeds with either a high or low oil content, but the number of viable eggs and nymphs hatched were higher for those fed with high-oil cotton seeds (Table 2). The lower egg viability of $D$. maurus females fed with cotton seeds with a low oil content may be related to the lower energy value of this food (Sahayaraj et al., 2011). Seed-sucking insects spend energy constantly and cannot survive periods of food scarcity without accumulating reserves in periods of food abundance by feeding on seeds with a high oil content (Arrese $\&$ Soulages, 2010). Therefore, fat reserves have direct implications on the energy metabolism of insects (Bártů et al., 2010; Toprak et al., 2020), being the most important reserve used to meet their energy demand during metamorphosis, diapause, embryogenesis, and flight (Toprak et al., 2020).

The body of $D$. maurus adults was longer and their head wider when fed with cotton seeds with a high oil content, while their body was longer and pronotum wider, with low-oil cotton seeds (Table 3). The abdominal width and antenna length of the stainer bug were greater for females fed with cotton with a high and low oil seed content; however, head length and interocular distance did not differ between treatments

Table 1. Survival and development period (days, mean \pm standard error) of the egg stage, of the first, second, third, fourth and fifth instars, and of the egg and total nymph stage of Dysdercus maurus (Hemiptera: Pyrrhocoridae) fed with seeds from cotton (Gossypium hirsutum) lines with a low (CNPA 2001-5087) or high (CNPA 2001-5581) oil content at $25 \pm 1^{\circ} \mathrm{C}$, $60 \pm 10 \%$ relative humidity, and 12 -hour photophase ${ }^{(1)}$.

\begin{tabular}{|c|c|c|c|c|c|c|}
\hline \multirow[t]{2}{*}{ Stage } & \multicolumn{3}{|c|}{ Low oil content } & \multicolumn{3}{|c|}{ High oil content } \\
\hline & Survival (\%) & Period (days) & $\mathrm{N}^{(2)}$ & Survival (\%) & Period (days) & $\mathrm{N}^{(2)}$ \\
\hline Egg & 100.0 & $5.00 \pm 0.00 \mathrm{~A}$ & 40 & 100.0 & $5.00 \pm 0.00 \mathrm{~A}$ & 40 \\
\hline First instar & 90.0 & $4.00 \pm 0.00 \mathrm{~A}$ & 36 & 90.0 & $4.00 \pm 0.00 \mathrm{~A}$ & 36 \\
\hline Second instar & 30.6 & $5.00 \pm 0.39 \mathrm{~A}$ & 11 & 91.7 & $3.00 \pm 0.00 \mathrm{~B}$ & 33 \\
\hline Third instar & 45.5 & $4.00 \pm 0.00 \mathrm{~B}$ & 5 & 96.9 & $5.91 \pm 0.35 \mathrm{~A}$ & 32 \\
\hline Fourth instar & 100.0 & $4.80 \pm 0.18 \mathrm{~A}$ & 5 & 96.9 & $6.29 \pm 0.39 \mathrm{~A}$ & 31 \\
\hline Fifth instar & 100.0 & $8.00 \pm 0.00 \mathrm{~B}$ & 5 & 96.8 & $9.70 \pm 0.27 \mathrm{~A}$ & 30 \\
\hline Total nymph stage & 12.5 & $26.60 \pm 0.22 \mathrm{~A}$ & 5 & 75.0 & $28.77 \pm 0.49 \mathrm{~A}$ & 30 \\
\hline
\end{tabular}

${ }^{(1)}$ Means followed by equal letters, uppercase in the lines, do not differ by Fisher's LSD test, at 5\% probability. ${ }^{(2)} \mathrm{N}$, number of individuals. 
or sexes. Conversely, the interaction between the weight of $D$. maurus adults with treatments and gender was significant (Figure 2), indicating variation in this parameter with cotton seed type and insect sex. Dysdercus maurus females, fed with cotton seeds with a high oil content, were heavier than those fed with a low oil content and than males from both treatments. Moreover, the weight of $D$. maurus females fed with cotton seeds with a low oil content was similar to that of males fed with either seed type. Therefore, food nutritional quality affects the morphology and weight of cotton stainer bugs, as reported for Dysdercus koenigii Fabricius, which showed higher biometric

Table 2. Reproductive characteristics (mean \pm standard error) of Dysdercus maurus (Hemiptera: Pyrrhocoridae) fed with seeds from cotton (Gossypium hirsutum) lines with a low (CNPA 2001-5087) or high (CNPA 2001-5581) oil content at $25 \pm 1^{\circ} \mathrm{C}, 60 \pm 10 \%$ relative humidity, and 12-hour photophase ${ }^{(1)}$.

\begin{tabular}{lcc}
\hline Variable & Low oil content & High oil content \\
\hline Preoviposition (days) & $7.50 \pm 0.67 \mathrm{a}$ & $10.54 \pm 1.28 \mathrm{a}$ \\
Oviposition (days) & $27.50 \pm 7.35 \mathrm{a}$ & $36.38 \pm 4.17 \mathrm{a}$ \\
Postoviposition (days) & $9.67 \pm 1.58 \mathrm{a}$ & $19.31 \pm 7.59 \mathrm{a}$ \\
Longevity (days) & $44.67 \pm 8.84 \mathrm{a}$ & $66.23 \pm 9.43 \mathrm{a}$ \\
Fecundity & $353.00 \pm 82.61 \mathrm{a}$ & $372.62 \pm 54.63 \mathrm{a}$ \\
Number of viable eggs & $51.17 \pm 17.37 \mathrm{~b}$ & $227.00 \pm 34.57 \mathrm{a}$ \\
Hatching (\%) & $16.23 \pm 3.66 \mathrm{~b}$ & $59.79 \pm 5.06 \mathrm{a}$ \\
\hline
\end{tabular}

(1)Means followed by the equal letters, lowercase in the lines, do not differ by Fisher's LSD test, at 5\% probability. parameters when fed with the MNH-886 cotton seed cultivar (higher oil content) than with Abelmoschus esculentus L. (lower oil content) (Naqqash et al., 2014). The body of Dysdercus nigrofasciatus Stål adults was larger when fed with cotton seeds with a high oil content than with seeds of Dombeya emarginata AE Bruce (Malvaceae) with a low oil content (Pearson, 1958). A larger body size and heavier weight increase the chances of the insect surviving during periods with limited or no food, facilitating its dispersal and fecundity (Panizzi et al., 2012; Sturm, 2016). Larger females of Dysdercus andreae (Linnaeus), Dysdercus bimaculatus Stål, Dysdercus fasciatus Signoret, Dysdercus mimus Blöte, Dysdercus mimulus Hussey, D. nigrofasciatus, Dysdercus superstitiosus Fabricius, and Dysdercus suturellus (Herrich-Schäffer) laid a greater number of eggs in a shorter time than the smaller ones (Derr et al., 1981).

The survival of second- and third-instar nymphs and of the total nymph stage (Table 1), as well as the number of viable eggs per D. maurus female (Table 2), were lower with cotton seeds with a low oil content. Since seed-sucking insects typically do not use other foods, the low-oil cotton varieties can reduce populations of the bug in areas with a history of its occurrence. This is important because it is possible to obtain, via conventional breeding, productive cotton varieties with a high fiber quality and a low oil content (Khan et al., 2010). This shows the need to select cotton lines with a low seed oil content in breeding programs for plant resistance to the cotton stainer bug.

Table 3. Morphological characteristics (mean \pm standard error) of Dysdercus maurus (Hemiptera: Pyrrhocoridae) adults fed with seeds from cotton (Gossypium hirsutum) lines with a low (CNPA 2001-5087) or high (CNPA 2001-5581) oil content at $25 \pm 1^{\circ} \mathrm{C}, 60 \pm 10 \%$ relative humidity, and 12 -hour photophase ${ }^{(1)}$.

\begin{tabular}{|c|c|c|c|c|}
\hline \multirow{2}{*}{$\begin{array}{l}\text { Morphological } \\
\text { characteristic (mm) }\end{array}$} & \multicolumn{2}{|c|}{ Low oil content } & \multicolumn{2}{|c|}{ High oil content } \\
\hline & Male & Female & Male & Female \\
\hline Body & $15.67 \pm 0.33 \mathrm{bA}$ & $15.00 \pm 0.55 \mathrm{bA}$ & $16.67 \pm 0.76 \mathrm{aA}$ & $17.20 \pm 0.20 \mathrm{aA}$ \\
\hline Abdominal width & $4.00 \pm 0.00 \mathrm{aB}$ & $4.60 \pm 0.24 \mathrm{aA}$ & $3.67 \pm 0.33 \mathrm{aB}$ & $5.00 \pm 0.00 \mathrm{aA}$ \\
\hline Head length & $1.50 \pm 0.22 \mathrm{aA}$ & $1.60 \pm 0.24 \mathrm{aA}$ & $1.33 \pm 0.21 \mathrm{aA}$ & $2.00 \pm 0.00 \mathrm{aA}$ \\
\hline Head width ${ }^{(2)}$ & $1.00 \pm 0.00 \mathrm{bA}$ & $1.20 \pm 0.20 \mathrm{bA}$ & $1.67 \pm 0.21 \mathrm{aA}$ & $2.00 \pm 0.00 \mathrm{aA}$ \\
\hline Interocular distance ${ }^{(3)}$ & $1.83 \pm 0.17 \mathrm{aA}$ & $2.00 \pm 0.00 \mathrm{aA}$ & $2.00 \pm 0.00 \mathrm{aA}$ & $2.00 \pm 0.00 \mathrm{aA}$ \\
\hline Antenna length & $7.67 \pm 0.21 \mathrm{aB}$ & $8.20 \pm 0.20 \mathrm{aA}$ & $7.83 \pm 0.31 \mathrm{aB}$ & $8.40 \pm 0.24 \mathrm{aA}$ \\
\hline Pronotum length & $1.33 \pm 0.21 \mathrm{aA}$ & $1.60 \pm 0.24 \mathrm{aA}$ & $1.00 \pm 0.00 \mathrm{bA}$ & $1.00 \pm 0.00 \mathrm{bA}$ \\
\hline Pronotum width ${ }^{(4)}$ & $2.33 \pm 0.21 \mathrm{aA}$ & $2.80 \pm 0.37 \mathrm{aA}$ & $2.00 \pm 0.00 \mathrm{bA}$ & $2.00 \pm 0.00 \mathrm{bA}$ \\
\hline
\end{tabular}

${ }^{(1)}$ Means followed by equal letters, lowercase in the columns and uppercase in the rows, do not differ by Tukey's test, at $5 \%$ probability. ${ }^{(2)}$ Between the outer edges of the eyes. ${ }^{(3)}$ Between the inner edges of the eyes. ${ }^{(4)} \mathrm{At}$ the humerus level. 


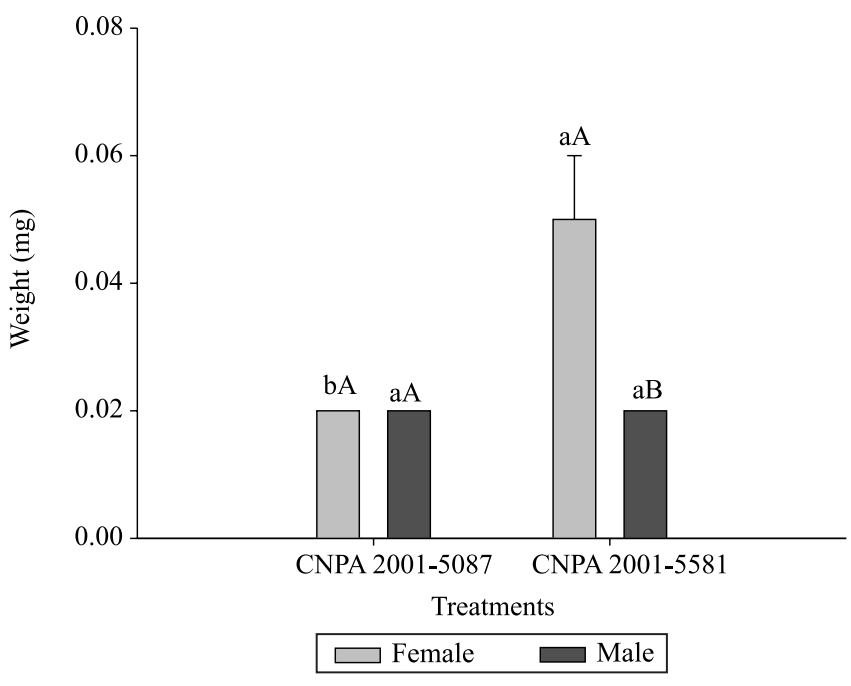

Figure 2. Weight of females and males of Dysdercus maurus (Hemiptera: Pyrrhocoridae) fed with seeds from cotton (Gossypium hirsutum) lines with a low (CNPA 2001-5087) or high (CNPA 2001-5581) oil content at $25 \pm 1{ }^{\circ} \mathrm{C}, 60 \pm 10 \%$ relative humidity, and 12-hour photophase. Bars followed by equal letters, lowercase per treatment or uppercase per genus, do not differ by Tukey's test, at 5\% probability.

\section{Conclusions}

1. The survival of second- and third-instar nymphs and of the total nymph stage of Dysdercus maurus is lower when the stainer bug is fed with cotton seeds with a low oil content.

2. The body length and head width of D. maurus adults are greater when the insect is fed with cotton seeds with a high oil content, but the length and width of the pronotum are smaller.

3. The weight of D. maurus females is greater when they are fed with cotton seeds with a high oil content, but that of the males is similar between those fed with seeds with either a high or low oil content.

4. Cotton genotypes with a low oil content can reduce cotton stainer bug populations.

\section{Acknowledgments}

To Empresa Brasileira de Pesquisa Agropecuária, for financial support (SEG code 22.14.01.025.00.00); and to the professional editor and proofreader David Michael Miller, for reviewing this article.

\section{References}

ALMEIDA, F.S.; GONÇALVES, L. Efeitos da temperatura e do alimento no desenvolvimento de Dysdercus maurus Distant (Hemiptera, Pyrrhocoridae). Revista Brasileira de Entomologia, v.51, p.506-511, 2007. DOI: https://doi.org/10.1590/S008556262007000400017.

AOCS. American Oil Chemists Society. AOCS official method. $5^{\text {th }}$ ed. Urbana, 2005.

ARAÚJO, A.E. de. Effect of the COVID-19 pandemic on Brazilian cotton sector. The ICAC Recorder, v.38, p.71-75, 2020.

ARRESE, E.L.; SOULAGES, J.L. Insect fat body: energy, metabolism, and regulation. Annual Review of Entomology, v.55, p.207-255, 2010. DOI: https://doi.org/10.1146/annurevento-112408-085356.

AZHER, F.; KHAN, M.M.; BILAL, M.; ASGHAR, I.; RASHEED, M.A.; ALI, S. The development of Antilochus coquebertii Fabr. (Heteroptera: Pyrrhocoridae) on different artificial diets. Journal of the Kansas Entomological Society, v.91, p.192-208, 2019. DOI: https://doi.org/10.2317/0022-8567-91.3.192.

BÁRTU゚, I.; TOMČALA, A.; SOCHA, R.; ŠIMEK, P.; KODRÍK, D. Analysis of the lipids mobilized by adipokinetic hormones in the firebug Pyrrhocoris apterus (Heteroptera: Pyrrhocoridae). European Journal of Entomology, v.107, p.509-520, 2010. DOI: https://doi.org/10.14411/eje.2010.058.

BELlAlOUI, N.; STETINA, S.R.; TURLEY, R.B. Cottonseed protein, oil, and mineral status in near-isogenic Gossypium hirsutum cotton lines expressing fuzzy/linted and fuzzless/ linted seed phenotypes under field conditions. Frontiers in Plant Science, v.6, art.137, 2015. DOI: https://doi.org/10.3389/ fpls.2015.00137.

BELLALOUI, N.; TURLEY, R.B. Effects of fuzzless cottonseed phenotype on cottonseed nutrient composition in near isogenic cotton (Gossypium hirsutum L.) mutant lines under well-watered and water stress conditions. Frontiers in Plant Science, v.4, art.516, 2013. DOI: https://doi.org/10.3389/fpls.2013.00516.

BEREZINA, N. Insects: novel source of lipids for a fan of applications. Oilseeds \& Fats Crops and Lipids, v.24, D402, 2017. DOI: https://doi.org/10.1051/ocl/2017032.

CARVALHO, L.P. de; RODRIGUES, J.I. da S.; FARIAS, F.J.C. Seleção de linhagens de algodão para alto teor de óleo. Pesquisa Agropecuária Brasileira, v.52, p.530-538, 2017. DOI: https://doi.org/10.1590/S0100-204X2017000700007.

DERR, J.A.; ALDEN, B.; DINGLE, H. Insect life histories in relation to migration, body size, and host plant array: a comparative study of Dysdercus. Journal of Animal Ecology, v.50, p.181-193, 1981. DOI: https://doi.org/10.2307/4039.

HE, Z.; SHANKLE, M.; ZHANG, H.; WAY, T.R.; TEWOLDE, H.; UCHIMIYA, M. Mineral composition of cottonseed is affected by fertilization management practices. Agronomy Journal, v.105, p.341-350, 2013. DOI: https://doi.org/10.2134/agronj2012.0351.

HE, Z.; ZHANG, H.; OLK, D.; SHANKLE, M.; WAY, T.; TEWOLDE, H. Protein and fiber profiles of cottonseed from upland cotton with different fertilizations. Modern Applied 
Science, v.8, p.97-105, 2014. DOI: https://doi.org/10.5539/mas. v8n4p97.

HE, Z.; ZHANG, H.; OLK, D.C. Chemical composition of defatted cottonseed and soy meal products. PLoS ONE, v.10, e0129933, 2015. DOI: https://doi.org/10.1371/journal.pone.0129933.

IBGE. Instituto Brasileiro de Geografia e Estatística. Levantamento Sistemático da Produção Agrícola. Available at: <https://www.sidra.ibge.gov.br/bda/agric $>$. Acessed on: Oct. 302020 .

JINDRA, M.; PALLI, S.R.; RIDDIFORD, L.M. The juvenile hormone signaling pathway in insect development. Annual Review of Entomology, v.58, p.181-204, 2013. DOI: https://doi.org/10.1146/annurev-ento-120811-153700.

JORGE, A.S.; LOMÔNACO, C. Size and partner choice in Dysdercus maurus Distant (Hemiptera: Pyrrhocoridae). Journal of Insect Behavior, v.2, p.148-152, 2009. DOI: https://doi.org/10.1007/s10905-008-9161-0.

KHAN, N.U.; MARWAT, K.B.; HASSAN, G.; FARHATULLAH; BATOOL, S.; MAKHDOOM, K.; AHAMAD, W.; KHAN, H.U. Genetic variation and heritability for cotton seed, fiber and oil traits in Gossypium hirsutum L. Pakistan Journal of Botany, v.42, p.615-625, 2010.

LIMA, A.M. da C.; GUITTON, N.; FERREIRA, O.V. Sôbre as espécies americanas do gênero Dysdercus boisduval (Hemiptera, Pyrrhocoridae, Pyrrhocorinae). Memórias do Instituto Oswaldo Cruz, v.60, p.21-58, 1962. DOI: https://doi.org/10.1590/S007402761962000100003.

MATTHÄUS, B.; ÖZCAN, M.M. Oil content, fatty acid composition and distributions of vitamin-E-active compounds of some fruit seed oils. Antioxidants, v.4, p.124-133, 2015. DOI: https://doi.org/10.3390/antiox4010124.

MENDES, L.O.T. Técnica de laboratório para a criação de insetos do gênero Dysdercus (Hemiptera: Pyrrhocoridae, manchadores do algodão. Bragantia, v.23, p.IX-XIV, 1964. DOI: https://doi.org/10.1590/S0006-87051964000100034.

MILANO, P.; CÔNSOLI, F.L.; ZÉRIO, N.G.; PARRA, J.R.P. Exigências térmicas de Dysdercus peruvianus Guérin-Méneville (Heteroptera: Pyrrhocoridae), o percevejo manchador do algodoeiro. Anais da Sociedade Entomológica do Brasil, v.28, p.233-238, 1999. DOI: https://doi.org/10.1590/S030180591999000200005.

MISHRA, A.; SINGH, A.K.; KUMAR, D. Stage- and sexdependent changes in the lipid profile of Dysdercus koenigii (Heteroptera: Pyrrhocoridae) during development. International Journal of Tropical Insect Science, v.24, p.236-241, 2004. DOI: https://doi.org/10.1079/IJT200428.

NAQQASH, M.N.; SAEED, S.; JALEEL, W.; ZAKA, S.M.; SAEED, Q. Effect of host plants on life history traits of Dysdercus koenigii (Hemiptera: Pyrrhocoridae). Journal of Biodiversity and Environmental Sciences, v.4, p.187-194, 2014.

PANIZZI, A.R. Suboptimal nutrition and feeding behavior of Hemipterans on less preferred plant food sources. Anais da Sociedade Entomológica do Brasil, v.29, p.1-12, 2000. DOI: https://doi.org/10.1590/S0301-80592000000100001.
PANIZZI, A.R.; PARRA, J.R.P.; SILVA, F.A.C. Insect bioecology and nutrition for integrated pest management (IPM). In: PANIZZI, A.R.; PARRA, J.R.P. (Ed.). Insect bioecology and nutrition for integrated pest management. Boca Raton: CRS Press, 2012. p.687-704.

PEARSON, E.O. The insect pests of cotton in tropical Africa. London: Commonwealth Institute of Entomology, 1958. 355p.

RIBEIRO JR., J.I. Análises estatísticas no SAEG. Viçosa: Ed. da UFV, 2001. 301p.

SAEED, S.; NAQQASH, M.N.; JALEEL, W. Toxicological studies on some important chemicals against Dysdercus koenigii Fabr (Hemiptera: Pyrrhocoridae). Pakistan Journal of Zoology, v.48, p.1249-1254, 2016.

SAHAYARAJ, K.; TOMSON, M.; KALIDAS, S. Artificial rearing of the red cotton bug, Dysdercus cingulatus using cotton seed-based artificial diet (Hemiptera: Pyrrhocoridae). Entomologia Generalis, v.33, p.283-288, 2011. DOI: https://doi.org/10.1127/entom.gen/33/2012/283.

SALEM, H.; KREUTZER, E.; SUDAKARAN, S.; KALTENPOTH, M. Actinobacteria as essential symbionts in firebugs and cotton stainers (Hemiptera, Pyrrhocoridae). Environmental Microbiology, v.15, p.1956-1968, 2013. DOI: https://doi.org/10.1111/1462-2920.12001.

SHAFIQ, M.; SARMAD, M.; ZAKA, S.M. Survival and fecundity of Antilochus coquebertii (Hemiptera: Pyrrhocoridae) on different stages of Dysdercus koenigii (Hemiptera: Pyrrhocoridae). Journal of the Kansas Entomological Society, v.92, p.526-535, 2020. DOI: https://doi.org/10.2317/0022-8567-92.3.526.

SHAH, S.I.A. The cotton stainer (Dysdercus koenigii): an emerging serious threat for cotton crop in Pakistan. Pakistan Journal of Zoology, v.46, p.329-335, 2014.

SHAH, S.I.A.; RAFIQ, M.; MALIK, T.H.; KHAN, I.R.; SHAH, S.A.S.; HUSSAIN, Z. Comparison of the newly introduced rearing methods of cotton stainer, Dysdercus koenigii (Hemiptera: Pyrrhocoridae) with classical methods. Pakistan Journal of Zoology, v.48, p.781-787, 2016. DOI: https://doi.org/10.13140/ RG.2.1.1135.4003.

SHARIF, I.; FAROOQ, J.; CHOHAN, S.M.; SALEEM, S.; KAINTH, R.A.; MAHMOOD, A.; SARWAR, G. Strategies to enhance cottonseed oil contents and reshape fatty acid profile employing different breeding and genetic engineering approaches. Journal of Integrative Agriculture, v.18, p.2205-2218, 2019. DOI: https://doi.org/10.1016/S2095-3119(18)62139-2.

SLÁMA, K.; LUKÁŠ, L. Hypermetabolic conversion of plant oil into water: endothermic biochemical process stimulated by juvenile hormone in the European firebug, Pyrrhocoris apterus L. International Journal of Insect Science, v.8, p.81-93, 2016. DOI: https://doi.org/10.4137/IJIS.S40566.

SONTAKKE, H.; BABA, I.; JAIN, S.M.; SAXENA, R.C.; BHAGEL, A.K.; JADHAW, B.V. Fecundity and fertility control of red cotton bug (Dysdercus cingulatus) by the extract of Psoralea corylifolia. International Journal of Research in Pharmaceutical and Biomedical Sciences, v.4, p.633-635, 2013. 
STURM, R. Relationship between body size and reproductive capacity in females of the black field cricket (Orthoptera, Gryllidae). Linzer Biologische Beiträge, v.48, p.1823-1834, 2016.

TOPRAK, U.; HEGEDUS, D.; DOĞAN, K.; GÜNEY, G. A journey into the world of insect lipid metabolism. Archives of Insect Biochemistry and Physiology, v.104, e21682, 2020. DOI: https://doi.org/10.1002/arch.21682.

VINOKUROV, K.; BEDNÁŘOVÁ, A.; TOMČALA, A.; STAŠKOVÁ, T.; KRISHNAN, N.; KODRÍK, D. Role of adipokinetic hormone in stimulation of salivary gland activities: the fire bug Pyrrhocoris apterus L. (Heteroptera) as a model species. Journal of Insect Physiology, v.60, p.58-67, 2014. DOI: https://doi.org/10.1016/j.jinsphys.2013.11.005.

VISSER, B.; WILLETT, D.S.; HARVEY, J.A.; ALBORN, H.T. Concurrence in the ability for lipid synthesis between life stages in insects. Royal Society Open Science, v.4, 160815, 2017. DOI: https://doi.org/10.1098/rsos.160815. 